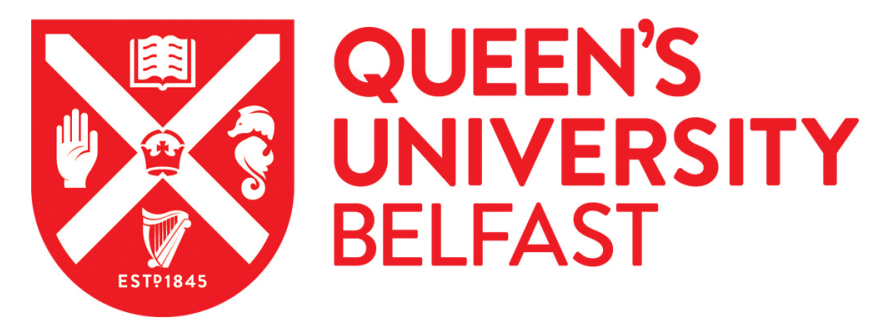

\title{
Fundamental studies of carbon capture using CaO-based materials
}

Sun, H., Wang, J., Liu, X., Shen, B., Parlett, C. M. A., Adwek, G. O., John Anthony, E., Williams, P. T., \& Wu, C. (2019). Fundamental studies of carbon capture using CaO-based materials. Journal of Materials Chemistry A, 7(16), 9977-9987. https://doi.org/10.1039/c8ta10472g

Published in:

Journal of Materials Chemistry A

Document Version:

Peer reviewed version

Queen's University Belfast - Research Portal:

Link to publication record in Queen's University Belfast Research Portal

Publisher rights

Copyright 2019 The Royal Society of Chemistry. This work is made available online in accordance with the publisher's policies. Please refer to any applicable terms of use of the publisher.

\section{General rights}

Copyright for the publications made accessible via the Queen's University Belfast Research Portal is retained by the author(s) and / or other copyright owners and it is a condition of accessing these publications that users recognise and abide by the legal requirements associated with these rights.

Take down policy

The Research Portal is Queen's institutional repository that provides access to Queen's research output. Every effort has been made to ensure that content in the Research Portal does not infringe any person's rights, or applicable UK laws. If you discover content in the Research Portal that you believe breaches copyright or violates any law, please contact openaccess@qub.ac.uk. 


\section{Fundamental studies of carbon capture using CaO-based materials}

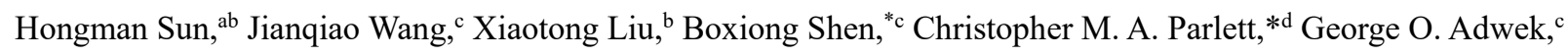

Edward J. Anthony, ${ }^{* e}$ Paul T. Williams*f and Chunfei Wu*abc

${ }^{a}$ School of Chemistry and Chemical Engineering, Queen's University Belfast, Belfast BT7 1NN, UK

${ }^{b}$ School of Engineering and Computer Science, University of Hull, Hull HU6 7RX, UK

${ }^{c}$ School of Energy and Environmental Engineering, Hebei University of Technology, Tianjin 300401, China

${ }^{d}$ School of Chemical Engineering and Analytical Science, University of Manchester, Manchester M1 3AL, UK

${ }^{e}$ Centre for Combustion and CCS, Cranfield University, Cranfield MK43 OAL, UK

${ }^{f}$ School of Chemical and Process Engineering, University of Leeds, Leeds LS2 9JT, UK

Abstract: Detailed understanding of the mechanisms of the fast stage during $\mathrm{CaO}$ carbonation is important to the design of novel efficient $\mathrm{CaO}$ materials. This work systematically studies the formation of $\mathrm{CaCO}_{3}$ product layer on the outside surface of $\mathrm{CaO}$ grains during the fast reaction stage for carbon capture using two types of $\mathrm{CaO}$ adsorbents. The carbonation at $400{ }^{\circ} \mathrm{C}$ filled the small pores in the commercial $\mathrm{CaO}$ grains and no distinct product layer of $\mathrm{CaCO}_{3}$ was observed. However, a distinct layer of $\mathrm{CaCO}_{3}$ with a thickness around $90 \mathrm{~nm}$ was observed on the outside surface of the commercial $\mathrm{CaO}$ grains after the carbonation at $600{ }^{\circ} \mathrm{C}$ because the internal pores in the $\mathrm{CaO}$ grain had been filled and a layer of $\mathrm{CaCO}_{3}$ product was deposited on the outside surface of the $\mathrm{CaO}$ grain. For sol-gel $\mathrm{CaO}$, the carbonation reaction is limited by the availability of useful porosity for the growth of $\mathrm{CaCO}_{3}$ product (confinement effect), instead of by the diffusion of ions in the critical layer of the $\mathrm{CaCO}_{3}$ product. No surface product layer was observed. Therefore, fabricating nano-CaO having dimensions less than the critical thickness of the $\mathrm{CaCO}_{3}$ layer $(\sim 90$ $\mathrm{nm}$ ) is of potentially great significance if it can be done cheaply and in bulk.

\footnotetext{
${ }^{*}$ Corresponding authors:

E-mail: c.wu@qub.ac.uk (C.Wu); p.t.williams@leeds.ac.uk (P.T. Williams), b.j.anthony@cranfield.ac.uk (E.J. Anthony); christopher.parlett@manchester.ac.uk (C. Parlett); shenbx@hebut.edu.cn (B. Shen).
} 


\section{Introduction}

Greenhouse gas especially $\mathrm{CO}_{2}$ emissions are responsible for climate change and the reduction of greenhouse gas is important to the sustainable development of modern society. ${ }^{1}$ It has been reported by the Intergovernmental Panel on Climate Change (IPCC) that the global risks of climate change are increasingly clear for agriculture, human health, ecosystems, and water supplies. The IPCC concluded in 2014 that the world was ill-prepared for such risks. ${ }^{2}$ Subsequently, the Parties to the United Nations Framework Convention on Climate Change (UNFCCC) reached a landmark agreement (the Paris Agreement) to accelerate actions and increase investments towards a sustainable and low-carbon future. ${ }^{3}$ Carbon capture and utilisation (CCU) have been attracting increasing attention. ${ }^{4,5} \mathrm{CO}_{2}$ absorption using amine solution is commercially available. However, as noted by Haszeldine et al. ${ }^{6}$ and Sadiq et al., ${ }^{7}$ an estimated $30 \%$ of power plant output is required for the regeneration of sorbents for carbon capture from post-combustion flue gas, because heating water in the amine sorbent causes large energy losses. On the other hand, using solid sorbents to capture $\mathrm{CO}_{2}$ is attractive, with the following advantages: (1) the lower heat capacity of solids significantly reduces the sensible energy required for sorbent regeneration; (2) corrosion problems caused by the use of amine solutions (the current standard carbon capture method) are avoided; ${ }^{8}(3)$ heat released during the exothermic carbon capture reaction at a high operating temperature (comparable to gas turbine exhaust temperature) ${ }^{9}$ can be extracted by steam for power generation enabling a highly efficient steam cycle. $\mathrm{CaO}$, as one of the high-temperature $\mathrm{CO}_{2}$ sorbents, has been investigated extensively because of its high reactivity for $\mathrm{CO}_{2}$ capture and high theoretical uptake capacity of $17.8 \mathrm{mmol} \mathrm{g}^{-1}$, as well as the extensive availability of $\mathrm{CaO}$ precursors possessing a low-cost nature. ${ }^{10-14}$ One $1 \mathrm{MWth}$ long-term pilot testing facility and a $1.7 \mathrm{MWth}$ CaL pilot were constructed in Technische Universität Darmstadt and La Pereda power plant, respectively. ${ }^{15,16} \mathrm{It}$ 

was found that the semi-industrial $\mathrm{CaL}$ plants achieved an outstanding $\mathrm{CO}_{2}$ capture efficiency $(>90 \%)$ with a good operation stability $(1200 \mathrm{~h})$. In addition, a $1.9 \mathrm{MWth}$ pilot plant constructed at 2013 in Taiwan confirmed that the $\mathrm{CaL}$ process is a promising technology for $\mathrm{CO}_{2}$ capture. ${ }^{17}$ However, one of the main limitations of $\mathrm{CaO}$ derived from natural precursors is the sorbent deactivation during the regeneration process due to the sintering of $\mathrm{CaO}$ particles at high regeneration temperature. ${ }^{18-20}$ This behaviour can be explained by considering the dramatic volume change between $\mathrm{CaO}$ and $\mathrm{CaO}$ to $\mathrm{CaCO}_{3}$; for example an increase from 16.7 to $36.9 \mathrm{~cm}^{3} \mathrm{~mol}^{-1}$ for $\mathrm{CaO}$ to $\mathrm{CaCO}_{3}$. Furthermore, there are two stages in the carbonation reaction of $\mathrm{CaO}$ : an initially fast reaction stage and a subsequently slow reaction stage. ${ }^{21-23}$ It is attributed that the reduction of carbonation rate in the slow stage was caused by the $\mathrm{CO}_{2}$ diffusion through the formed $\mathrm{CaCO}_{3}$ product. $^{22}$ In the carbonation process, the ratio of reaction rates between the fast and slow reaction stages was around $100 .^{24}$ This value is in good consistency with the ratio of diffusion coefficients for $\mathrm{CaO}\left(0.3 \mathrm{~cm}^{2} \mathrm{~s}^{-1}\right)$ and $\mathrm{CaCO}_{3}\left(0.003 \mathrm{~cm}^{2} \mathrm{~s}^{-1}\right) \cdot{ }^{22,25}$ Therefore, Barker suggested that there was a critical $\mathrm{CaCO}_{3}$ product layer at which the carbonation reaction rate was determined by the $\mathrm{CO}_{2}$ diffusion. ${ }^{22}$ During the fast reaction stage, $\mathrm{CaCO}_{3}$ grew on the surface of $\mathrm{CaO}$ grains and then collapsed to form a continuous layer on the outside surface of the unreacted adsorbent. Thereafter, the fast reaction stage during the $\mathrm{CaO}$ carbonation suddenly finished. ${ }^{26}$ Thus, the initially fast stage and the subsequently slow stage were controlled by the kinetic reaction and $\mathrm{CO}_{2}$ diffusion through the $\mathrm{CaCO}_{3}$ product layer, respectively. ${ }^{27,28}$

To better understand the fast stage during the $\mathrm{CaO}$ carbonation, which is particularly essential for practical applications due to the short reaction time, the critical thickness of the $\mathrm{CaCO}_{3}$ product layer has been extensively studied. Barker ${ }^{22}$ demonstrated a "critical carbonate layer thickness" of $22 \mathrm{~nm}$ at which the carbonation reaction rate started to be controlled by $\mathrm{CO}_{2}$ diffusion limitation. 
However, the estimating equation adopted in that research was confounded by the uncertainties in the carbonation model. A better understanding of pore model coupled with a carbonation pattern across $\mathrm{CaO}$ particles was required in this model. In order to eliminate the influences of the unquantifiable and complex morphology in natural materials, the long-duration carbonation reaction on non-porous $\mathrm{CaO}$ particles was carried out by Mess et al. ${ }^{29}$ It was found that the $\mathrm{CaCO}_{3}$ product layer was homogeneous and exhibited a thickness up to $2 \mu \mathrm{m}$ under very severe carbonation conditions $\left(850{ }^{\circ} \mathrm{C}\right.$ and $1.2 \mathrm{MPa}$ of $\mathrm{CO}_{2}$ for $2000 \mathrm{~min}$ ). Subsequently, Alvarez and Abanades ${ }^{30}$ refined the model proposed by Barker ${ }^{22}$ and suggested that before the maximum product thickness was reached, the small pores in the sorbent were completely filled. In their proposed model, a $\mathrm{CaCO}_{3}$ layer was generated on the outside surface of $\mathrm{CaO}$ grains in the carbonation reaction and an average value of $49 \mathrm{~nm}$ (standard deviation is around 19\%) was determined.

However, the critical thickness of the $\mathrm{CaCO}_{3}$ layer has only been estimated by means of computer-aided modeling. ${ }^{22,26,29,30}$ There has been no direct observation and measurement of the critical thickness of $\mathrm{CaCO}_{3}$ product layer formed in the $\mathrm{CaO}$ carbonation reaction. Thus, a detailed experimental study is highly desirable for the design of novel $\mathrm{CaO}$ adsorbents and the understanding of mechanisms of $\mathrm{CaO}$ carbonation.

In addition, most of the $\mathrm{CaO}$ carbonation work in the open literature was carried out at temperatures higher than $500{ }^{\circ} \mathrm{C}$. Only limited information on low-temperature carbonation of $\mathrm{CaO}$ at around 400 ${ }^{\circ} \mathrm{C}$ has been reported due to the relatively low reaction rate and low capacity of carbon capture. ${ }^{31,32}$ We have found that there are two stages of fast $\mathrm{CaO}$ carbonation maximising the reaction rate at 400 and $600{ }^{\circ} \mathrm{C}$, respectively. Normally, one stage of the fast carbonation reaction was reported in other work for non-isothermal $\mathrm{CaO}$ carbonation when the temperature was increased from room temperature to $900{ }^{\circ} \mathrm{C} .{ }^{33}$ However, the presence of the carbonation gap between 400 and $600{ }^{\circ} \mathrm{C}$ has 
not been clearly understood.

Furthermore, a potentially novel intensified process combining $\mathrm{CO}_{2}$ capture and utilisation at around $400{ }^{\circ} \mathrm{C}$ could be very interesting. For example, Duyar et al. ${ }^{34}$ reported that using a dual-functional catalyst for $\mathrm{CO}_{2}$ capture at $320{ }^{\circ} \mathrm{C}$, followed by the introduction of $\mathrm{H}_{2}$ at the same reaction temperature, resulted in the regeneration of sorbent and the production of methane. In this scenario, the regeneration of sorbents and the conversion of captured $\mathrm{CO}_{2}$ were processed without an energy-intensive thermal-swing process. Therefore, it is of interest to understand the formation of the $\mathrm{CaCO}_{3}$ layer during $\mathrm{CaO}$ carbonation at key reaction temperatures of $400{ }^{\circ} \mathrm{C}$ and $600{ }^{\circ} \mathrm{C}$. In this work, two types of $\mathrm{CaO}$ adsorbents possessing different porosities were studied in relation to the critical thickness of $\mathrm{CaCO}_{3}$ product layer.

\section{Experimental section}

\subsection{Adsorbent preparation}

A standard sol-gel process proposed by Santos et al. ${ }^{35}$ was used to synthesise a $\mathrm{CaO}$ adsorbent. Predetermined amounts of calcium nitrate tetrahydrate $\left(\mathrm{Ca}\left(\mathrm{NO}_{3}\right)_{2} \cdot 4 \mathrm{H}_{2} \mathrm{O}\right.$, Sigma-Aldrich, 99.99\%) and citric acid monohydrate $\left(\mathrm{C}_{6} \mathrm{H}_{8} \mathrm{O}_{7} \cdot \mathrm{H}_{2} \mathrm{O}\right.$, Sigma-Aldrich, 99.99\%) acting as chelation agent, were added to the distilled water at room temperature (water and citric acid to metal ion molar ratios were $40: 1$ and $1: 1$, respectively). The mixture was continuously stirred at $80{ }^{\circ} \mathrm{C}$ to form a translucent pale-yellow sol with good dispersion. After drying overnight at $130{ }^{\circ} \mathrm{C}$ of the prepared sol, the translucent pale-yellow sol turned into a low-density foam. The obtained foam was then calcined in a muffle furnace at $850{ }^{\circ} \mathrm{C}$ for $5 \mathrm{~h}$ with a heating rate of $2{ }^{\circ} \mathrm{C} \mathrm{min}^{-1}$. This synthesized sample was designated as sol-gel $\mathrm{CaO}$. A commercial $\mathrm{CaO}$ (Sigma-Aldrich, 99.99\%) was used as the reference adsorbent after dried overnight at $130{ }^{\circ} \mathrm{C}$. 


\subsection{Carbonation/calcination tests}

The carbon capture performance of adsorbents was conducted in both a fixed-bed reactor (as shown in Fig. 1) and a thermogravimetric analyser (TGA, SDT Q600). In the case of the fixed-bed test, $500 \mathrm{mg}$ of adsorbent was loaded into the sample tube $(6.35 \mathrm{~mm}$ in diameter). Both the carbonation and calcination processes were performed with a temperature-swing process with a heating rate of $10{ }^{\circ} \mathrm{C} \min ^{-1}$ under $15 \% \mathrm{CO}_{2}$ balanced with $\mathrm{N}_{2}$. The total flow rate of gases was controlled at 100 $\mathrm{mL} \mathrm{min}^{-1}$. The reacted $\mathrm{CaO}$ samples produced at both $400{ }^{\circ} \mathrm{C}$ and $600{ }^{\circ} \mathrm{C}$ in the fixed-bed reactor were denoted as sol-gel FB-400 and sol-gel FB-600 for the sol-gel CaO, and FB-400 and FB-600 for the commercial $\mathrm{CaO}$, respectively. After calcination, the sample was denoted as FB-des. The same carbonation/calcination test was repeated over 3 cycles.

During the TGA test, around $15 \mathrm{mg}$ of adsorbent was placed in an alumina crucible and heated to $800{ }^{\circ} \mathrm{C}$ with a heating rate of $20{ }^{\circ} \mathrm{C} \min ^{-1}$ under the $\mathrm{N}_{2}$ atmosphere $\left(100 \mathrm{~mL} \mathrm{~min}^{-1}\right)$. When the temperature decreased to room temperature, further increasing the temperature to $400{ }^{\circ} \mathrm{C}, 15 \% \mathrm{CO}_{2}$ was used to carbonate the sample for $10 \mathrm{~h}$ and then increase the temperature to $600{ }^{\circ} \mathrm{C}$ for $30 \mathrm{~min}$. The carbonation conversion was calculated as follows: ${ }^{36}$

$$
\mathrm{X}(\%)=\frac{\mathrm{m}_{t}-\mathrm{m}_{0}}{\mathrm{~m}_{0}} \cdot \frac{\mathrm{M}_{\mathrm{CaO}}}{\mathrm{M}_{\mathrm{CO}_{2}}} \cdot 100 \%
$$

where $\mathrm{X}$ is the carbonation conversion, $\mathrm{m}_{0}$ is the mass of the sample after calcination, $\mathrm{m}_{\mathrm{t}}$ is the mass of the sample after carbonation for $\mathrm{t}$ minutes, and $\mathrm{M}_{\mathrm{CaO}}$ and $\mathrm{M}_{\mathrm{CO}_{2}}$ are the mole masses of $\mathrm{CaO}$ and $\mathrm{CO}_{2}$, respectively.

\subsection{Characterisation of adsorbents}

Powder X-ray diffraction (XRD) was performed on a PANalytical empyrean series 2 diffractometer with $\mathrm{Cu} \mathrm{Ka}$ radiation. Data were analysed by X'pert Highscore plus software. $\mathrm{N}_{2}$ adsorption-desorption isotherms were collected using an ASAP 2000 analyser at $-196{ }^{\circ} \mathrm{C}$. The 
Brunauer-Emmett-Teller (BET) surface area was calculated using the adsorption branch data at the relative pressure $\left(\mathrm{P} / \mathrm{P}_{0}\right)$ from 0.06 to 0.2 , and the micropore volume $\left(\mathrm{V}_{\text {micro }}\right)$ was calculated by the t-plot method. ${ }^{37}$ The pore size distribution was calculated by the Barrett-Joyner-Halenda (BJH) method using nitrogen desorption branch data.

The surface morphology and microstructure of samples were characterised using scanning electron microscopy (SEM, a Stereoscan 360) and transmission electron microscopy (TEM, JEOL 2010), respectively. For TEM analysis of bulky solid samples, the samples were ground, dispersed with acetone, and then deposited on a $\mathrm{Cu}$ grid covered with a perforated carbon membrane.

A Nanolab Dualbeam focused ion beam (FIB)-SEM coupled with an energy-dispersive X-ray spectroscopy (EDX) and TEM coupled with selected area electron diffraction patterns, were used to characterise and examine the critical thickness of the product layer deposited on the carbonated adsorbents. For FIB-SEM analysis, the samples were cut using a focused ion beam to produce small cross-section samples, which were attached to TEM grids using a platinum binder. After that, the grids with the cross-section samples were analysed using TEM.

The crystalline phase change during the carbonation process for $\mathrm{CaO}$ and sol-gel $\mathrm{CaO}$ was detected by the in-situ XRD. The Bruker D8 Advance XRD equipped with an Anton-Paar XRK-900 high-pressure XRD cell and a $\mathrm{Cu} k \alpha$ source $(0.154 \mathrm{~nm})$ was conducted to collect the XRD patterns. Sample activation was conducted at $800{ }^{\circ} \mathrm{C}$ in pure $\mathrm{N}_{2}\left(1 \mathrm{bar}, 50 \mathrm{~mL} \mathrm{~min}{ }^{-1}\right)$ for $60 \mathrm{~min}$, with a heating rate of $10{ }^{\circ} \mathrm{C} \mathrm{min}^{-1}$ before cooling to $400{ }^{\circ} \mathrm{C}$ for data collection. The sample was pre-treated with $15 \% \mathrm{CO}_{2}$ balanced with $\mathrm{N}_{2}$ for 60 min and XRD patterns were continuously collected with the scanning ranging from $22.5^{\circ}$ to $40^{\circ}$ with a step size of $0.1^{\circ}$ and dwell time of $1 \mathrm{~s}(15$ min scans yielding 4 patterns to observe the phase changes). 


\section{Results and discussion}

\subsection{Characterisations of adsorbents}

$\mathrm{N}_{2}$ adsorption-desorption isotherms and pore size distributions were conducted to determine the structure of the $\mathrm{CaO}$ materials (Fig. 2). The textural properties of different $\mathrm{CaO}$ adsorbents are summarised in Table 1. The BET surface area $\left(38.51 \mathrm{~m}^{2} \mathrm{~g}^{-1}\right)$ and total pore volume $\left(0.1527 \mathrm{~cm}^{3} \mathrm{~g}^{-1}\right)$ of the sol-gel $\mathrm{CaO}$ are much higher than those of the commercial $\mathrm{CaO}\left(20.96 \mathrm{~m}^{2} \mathrm{~g}^{-1}\right.$ and $0.0314 \mathrm{~cm}^{3}$ $\mathrm{g}^{-1}$, respectively) due to the presence of micro-scale agglomerates generated by the voids between the nano-scale grains, ${ }^{35}$ which favor $\mathrm{CO}_{2}$ carbonation performance. ${ }^{38,}{ }^{39}$ The $\mathrm{BJH}$ pore size distribution (Fig. 2b) indicates the formation of abundant mesopores and macropores ranging from 2 to $100 \mathrm{~nm}$ in the sol-gel $\mathrm{CaO}$. The morphologies of the commercial $\mathrm{CaO}$ and the sol-gel $\mathrm{CaO}$ are displayed in Fig. 3a and b, respectively. The commercial $\mathrm{CaO}$ possesses a compact structure with a smooth surface and the diameter of $\mathrm{CaO}$ grains ranges from 1.5 to $2 \mu \mathrm{m}$ (Fig. S1a). Compared to the commercial $\mathrm{CaO}$, the sol-gel $\mathrm{CaO}$ exhibits a much more fluffy and porous structure. In addition, the diameter of the sol-gel $\mathrm{CaO}$ grains ranges from $120 \mathrm{~nm}$ to $180 \mathrm{~nm}$ as shown in Fig. S1b. Pores less than $10 \mathrm{~nm}$ are observed in the commercial $\mathrm{CaO}$ as shown in Fig. $3 \mathrm{~g}$ in agreement with the distribution of small pores ranging from $2 \mathrm{~nm}$ to $10 \mathrm{~nm}$ in Fig. 2b. However, mesopores composed of nano-sized grains are observed only in the sol-gel $\mathrm{CaO}$, which is consistent with the $\mathrm{BJH}$ size distribution (Fig. 2b).

\subsection{Carbon capture testing}

The carbonation of $\mathrm{CaO}$ at 400 and $600{ }^{\circ} \mathrm{C}$ was observed using a fixed-bed reactor. As shown in Fig. 4a and $\mathrm{b}$, both the commercial $\mathrm{CaO}$ and the sol-gel $\mathrm{CaO}$ exhibited a dramatic $\mathrm{CaO}$ conversion at $400{ }^{\circ} \mathrm{C}$. However, a further increase in temperature resulted in a sudden reduction of carbonation rate at around $500{ }^{\circ} \mathrm{C}$ for both samples. The carbonation rate of the $\mathrm{CaO}$ increased again when the 
temperature reached $600{ }^{\circ} \mathrm{C}$. However, as shown in Table 2, the $\mathrm{CO}_{2}$ uptake, from the $1^{\text {st }}$ cycle to the $2^{\text {nd }}$ cycle, declined dramatically at a carbonation temperature of around $400{ }^{\circ} \mathrm{C}$ for both the commercial $\mathrm{CaO}$ and the sol-gel $\mathrm{CaO}$, while only a slight decrease of $\mathrm{CO}_{2}$ uptake is observed after carbonation at $600{ }^{\circ} \mathrm{C}$. Compared to the $2^{\text {nd }}$ cycle performance of $\mathrm{CO}_{2}$ capture, the $3^{\text {rd }}$ cycle carbon capture exhibited slightly decreased carbonation rates at both $400^{\circ} \mathrm{C}$ and $600{ }^{\circ} \mathrm{C}$. It is noted that all characterizations of materials are from $1^{\text {st }}$ cycle carbon capture. It is suggested that with the increase of carbonation/calcination cycles, less effect was observed on the carbon capture performance at the second carbonation stage at around $600{ }^{\circ} \mathrm{C}$. A more detailed understanding of mechanisms in relation to the increase of carbonation/calcination cycles is suggested for future.

In order to eliminate the influence of moisture and other impurities inside the sorbent, both the commercial $\mathrm{CaO}$ and the sol-gel $\mathrm{CaO}$ samples were heated to $800{ }^{\circ} \mathrm{C}$ under $\mathrm{N}_{2}$ atmosphere; then the samples were cooled to $400{ }^{\circ} \mathrm{C}$ for the $\mathrm{CO}_{2}$ capture stage. Fig. S2 shows that the weight of the $\mathrm{CaO}$ sample was increased initially due to the carbonation reaction and then showed relative stability at $400{ }^{\circ} \mathrm{C}$, indicating that carbonation of $\mathrm{CaO}$ was almost completed at $400{ }^{\circ} \mathrm{C}$. In addition, the sample was held at $400{ }^{\circ} \mathrm{C}$ for $10 \mathrm{~h}$ prior to heating it to $600{ }^{\circ} \mathrm{C}$ for further carbonation. This is to ensure that $\mathrm{CaO}$ carbonation at $600{ }^{\circ} \mathrm{C}$ was not due to incomplete carbonation at $400{ }^{\circ} \mathrm{C}$. As shown in Fig. S2, carbonation is clearly observed at $600{ }^{\circ} \mathrm{C}$ indicating the presence of a true two-stage fast carbonation of $\mathrm{CaO}$ at around 400 and $600{ }^{\circ} \mathrm{C}$, respectively.

A few studies have reported the existence of a reaction rate gap in the $\mathrm{CaO}$ carbonation when the temperature ranges from 400 to $600{ }^{\circ} \mathrm{C}$. Bhatia and Perlmutter ${ }^{40}$ proposed that when the temperature was lower than $515^{\circ} \mathrm{C}$, the $\mathrm{CaO}$ carbonation reaction as shown in Eq. (2) and (3) took place on the pore surface and was governed by the diffusion of $\mathrm{CO}_{2}$ molecules with an activation energy of 88.9 $\pm 3.7 \mathrm{~kJ} \mathrm{~mol}^{-1}$. The ionic diffusion process is shown in Fig. S3a. This is consistent with the 
observation of $\mathrm{CaO}$ carbonation at around $400{ }^{\circ} \mathrm{C}$ in this work. However, increasing the temperature of $\mathrm{CaO}$ carbonation to higher than $515{ }^{\circ} \mathrm{C}$, the reaction was reported to take place at the interface between $\mathrm{CaO}$ and $\mathrm{CaCO}_{3}$ as described in Eq. (4), where $\mathrm{CO}_{3}{ }^{2-}$ is the diffusion species with an activation energy about $179.2 \pm 7.0 \mathrm{~kJ} \mathrm{~mol}^{-1}{ }^{40}$ as shown in Fig. S3b.

$\mathrm{T}<515^{\circ} \mathrm{C}$, carbonation occurs at the pore surface:

$$
\mathrm{CO}_{2}(\mathrm{~g}) \rightleftharpoons\left(\mathrm{CO}_{2}\right) \text { ads }
$$

$\left(\mathrm{CO}_{2}\right)$ ads $+\mathrm{O}^{2-} \rightarrow \mathrm{CO}_{3}^{2-}$

$\mathrm{T}>515^{\circ} \mathrm{C}$, carbonation occurs at the $\mathrm{CaO}-\mathrm{CaCO}_{3}$ interface:

$$
\mathrm{CO}_{3}{ }^{2-}+\mathrm{CaO} \rightarrow \mathrm{CaCO}_{3}+\mathrm{O}^{2-}
$$

\subsection{Mechanisms of $\mathrm{CaO}$ carbonation}

$\mathrm{XRD}$ results for the $\mathrm{CaO}$ samples are shown in Fig. 5. For the fresh commercial $\mathrm{CaO}$ and sol-gel $\mathrm{CaO}$ samples, only one $\mathrm{CaO}$ phase is observed. After carbonation at $400{ }^{\circ} \mathrm{C}$, the spent adsorbents exhibit a weak diffraction peak at $2 \theta=29.4^{\circ}$, indicating the characteristic peak of $\mathrm{CaCO}_{3}\left(\begin{array}{lll}1 & 0 & 4\end{array}\right){ }^{41}$

The XRD patterns for the commercial $\mathrm{CaO}$ and the sol-gel $\mathrm{CaO}$ after carbonation at $600{ }^{\circ} \mathrm{C}$ exhibit much stronger diffraction peaks at similar positions. This indicates that more $\mathrm{CaCO}_{3}$ phases were generated at $600{ }^{\circ} \mathrm{C}$ compared with the reacted $\mathrm{CaO}$ sorbents obtained at $400{ }^{\circ} \mathrm{C}$. The diffraction peaks of $\mathrm{CaCO}_{3}$ disappear after increasing the carbonation temperature to $800{ }^{\circ} \mathrm{C}$. This is attributed to the decomposition of $\mathrm{CaCO}_{3}$ at $800{ }^{\circ} \mathrm{C}$.

After carbonation of the commercial $\mathrm{CaO}$ and the sol-gel $\mathrm{CaO}$ at 400 and $600{ }^{\circ} \mathrm{C}$, similar morphologies are observed for both FB-400 and FB-600 (Fig. 3c and e). From Fig. 3d and f, the mesopores in the sol-gel $\mathrm{CaO}$ appear to diminish after carbonation at 400 and $600{ }^{\circ} \mathrm{C}$. Nevertheless, there are many attachments on the surface of the sol-gel $\mathrm{CaO}$ carbonated at $400{ }^{\circ} \mathrm{C}$ observed in the SEM images (Fig. 3d), showing that the mesopores between small grains are well connected. 
However, the sol-gel $\mathrm{CaO}$ experienced a dramatic decrease of pores and the growth of grains after carbonation at $600{ }^{\circ} \mathrm{C}$ due to the volume increase of the sorbent, as shown in Fig. 3f.

FIB-SEM coupled with EDX was used to measure the critical thickness of the $\mathrm{CaCO}_{3}$ product layer as shown in Fig. 6. It is noted that the top layer observed in the cross-section was coated with indium which was used to protect the surface during the cutting of the $\mathrm{CaO}$ samples. ${ }^{42}$ As for the commercial $\mathrm{CaO}$, no product layer can be observed after carbonation at $400{ }^{\circ} \mathrm{C}$ as shown in Fig. 6 a. However, a uniform distribution of carbon element is shown in EDX mapping (Fig. S4) implying that $\mathrm{CaCO}_{3}$ was formed uniformly within the commercial $\mathrm{CaO}$ during carbonation at $400{ }^{\circ} \mathrm{C}$. The existence of $\mathrm{CaCO}_{3}$ is also confirmed from the XRD analysis of FB-400 (Fig. 5a). The commercial $\mathrm{CaO}$ sample has a bulk particle size around $3 \mathrm{~mm}$ with small grains (around $1.5 \mu \mathrm{m}$ ) containing small pores ranging from $2 \mathrm{~nm}$ to $10 \mathrm{~nm} \cdot{ }^{43,44}$ It appears that carbonation of the commercial $\mathrm{CaO}$ at $400{ }^{\circ} \mathrm{C}$ is dominated by the kinetic reaction between $\mathrm{CaO}$ and $\mathrm{CO}_{2}$, and the small pores in the grains were filled with the $\mathrm{CaCO}_{3}$ formed. Although a layer of $\mathrm{CaCO}_{3}$ is not observed on the FB-400 sample, EDX analysis (Fig. 7a and b) shows that the concentration of carbon in relation to $\mathrm{CaCO}_{3}$ inside the small grains of the commercial $\mathrm{CaO}$ was around $5.44 \%$, which is lower than the concentration of carbon on the surface of the commercial $\mathrm{CaO}(6.16 \%)$ (FB-400). This indicates that the outer layer of the $\mathrm{CaO}$ was concentrated with $\mathrm{CaCO}_{3}$ in the fast carbonation stage at $400{ }^{\circ} \mathrm{C}$. A distinct layer is observed after the $\mathrm{CaO}$ sample was carbonated at $600{ }^{\circ} \mathrm{C}$. It is suggested that after the carbonation, the internal pores in the grain have been filled and a layer of product was formed on the outside of the grain. It can be seen from Fig. S5 that the average thickness of the product $\left(\mathrm{CaCO}_{3}\right)$ is around $90 \mathrm{~nm}$. It is noted that the FB-600 sample was obtained when the maximum carbonation rate was reached during carbonation at $600{ }^{\circ} \mathrm{C}$ in the fixed-bed reactor. In addition, the distributions of oxygen and carbon elements show a gradual increase from the interior to the surface 

of the $\mathrm{CaO}$ grains as shown in the EDX mapping of the FB-600 (Fig. 6f and g). By contrast, the weight percentage of calcium exhibits a decrease from the inner grains to the surface of the FB-600 $\mathrm{CaO}$. Similar results are observed in Fig. $7 \mathrm{c}$ and $\mathrm{d}$. The weight percentage of carbon on the surface of the commercial $\mathrm{CaO}$ grains $(5.96 \%)$ is twice as much as in the interior of the $\mathrm{CaO}$ grains $(2.99 \%)$. This phenomenon suggests that the carbonation reaction happened on the interface between $\mathrm{CaO}$ and $\mathrm{CaCO}_{3} . \mathrm{CO}_{2}$ diffuses through the $\mathrm{CaCO}_{3}$ layer as $\mathrm{CO}_{3}{ }^{2-}$ ions. ${ }^{40}$ Therefore, the concentration of carbon elements corresponding to $\mathrm{CO}_{3}{ }^{2-}$ ions is higher on the surface of $\mathrm{CaO}$ grains after carbonation at $600{ }^{\circ} \mathrm{C}$, compared to the carbon concentration inside the $\mathrm{CaO}$ grains.

In this stage, $\mathrm{CO}_{3}{ }^{2-}$ ions can decompose to produce $\mathrm{CO}_{2}$ and $\mathrm{O}^{2-}$ as shown in Eq. (4). $\mathrm{CO}_{2}$ molecule transfers to a neighboring, similarly vacated site, while $\mathrm{CO}_{2}$ produced elsewhere moves to take its place and reform the $\mathrm{CO}_{3}{ }^{2-}$. Therefore, the $\mathrm{CO}_{2}$ molecule diffuses from site to site through the $\mathrm{CaCO}_{3}$ product layer, until ultimately the carbonation reaction occurs at the interface between $\mathrm{CaO}$ and $\mathrm{CaCO}_{3}$. The ionic diffusion process is shown in Fig. S3b. A higher activation energy, about 179.2 $\pm 7.0 \mathrm{~kJ} \mathrm{~mol}^{-1}$, is required for the decomposition of $\mathrm{CO}_{3}{ }^{2-}$. This activation energy corresponds to a carbonation temperature around $600{ }^{\circ} \mathrm{C}$, where the second-stage fast $\mathrm{CaO}$ carbonation occurred. The sudden change in activation energy between 500 and $600{ }^{\circ} \mathrm{C}$ could also be due to the phase change of $\mathrm{CaCO}_{3}$ from aragonite to calcite. ${ }^{45}$ The diffusion of ions within aragonite is much easier than calcite. The diffusion of ions (e.g., $\mathrm{CO}_{3}{ }^{2-}$ ) is related to Tammann temperature (which is half the absolute melting point, and the temperature at which bulk diffusion starts to become significant), which is around $412{ }^{\circ} \mathrm{C}$ for aragonite and around $650{ }^{\circ} \mathrm{C}$ for calcite. In-situ XRD analysis of $\mathrm{CaO}$ carbonation at a temperature of $750{ }^{\circ} \mathrm{C}$ has been investigated and, to date, only calcite was reported 46. However, at a lower carbonation temperature of $450{ }^{\circ} \mathrm{C}$, aragonite-type $\mathrm{CaCO}_{3}$ appears to be formed, according to in-situ XRD experimental tests. ${ }^{47}$ 
In this work, the phase changes in the carbonation reaction at different temperatures were

278 investigated using an in-situ XRD equipment, as shown in Fig. 8. It is found that calcite was the 279 only phase of $\mathrm{CaCO}_{3}$ observed with the increase of both the reaction time and temperature.

280 Therefore, the sudden change of $\mathrm{CaO}$ carbonation is unlikely due to the phase change of $\mathrm{CaCO}_{3}$

281 from aragonite to calcite during the carbonation of $\mathrm{CaO}$ samples. However, a high-resolution 282 synchrotron XRD could be used to further confirm the absence of aragonite during $\mathrm{CaO}$ carbonation, which might exist as an intermediate product.

In order to understand the influence of temperature on the critical thickness of the product layer during the fast $\mathrm{CaO}$ carbonation, FIB-TEM coupled with selected-area electron diffraction patterns were produced, as shown in Fig. 9. Even though no $\mathrm{CaCO}_{3}$ product layer was observed in Fig. 9A, (012) and (104) crystal phases of $\mathrm{CaCO}_{3}$ were observed in the electron diffraction pattern (Fig. 9a) which is in agreement with XRD results in Fig. 5a. In addition, $(001)$ crystal phase $\left(\mathrm{Ca}(\mathrm{OH})_{2}\right)$ was observed due to the reaction between the thin FIB-TEM sample (around $100 \mathrm{~nm}$ ) and moisture in the air. Three distinct layers and single-crystal characteristics after the carbonation at $600{ }^{\circ} \mathrm{C}$ are shown in Fig. 9B and Fig. 9b, respectively. The outside layer was caused by the coating of indium and platinum. The compact layer in the middle was the formed $\mathrm{CaCO}_{3}$ product layer, with a thickness around $90 \mathrm{~nm}$. This phenomenon indicates that, as with commercial $\mathrm{CaO}$, carbonation at $400{ }^{\circ} \mathrm{C}$ and $600{ }^{\circ} \mathrm{C}$ involves filling $\mathrm{CaCO}_{3}$ in the small pores in the grains, and a product layer deposited on the outside of the grains, respectively.

\subsection{Influence of porous structure}

Abundant mesopores, ranging from 2 to $100 \mathrm{~nm}$, were generated by the lamellar structure in the sol-gel $\mathrm{CaO}$ (Fig. 3b), which enhance the fast and kinetically-limited reaction stage. In addition, large pore volume favors gas diffusion in the pore space of adsorbents. ${ }^{48}$ Therefore, the sol-gel $\mathrm{CaO}$ 
performed a higher carbon capture capacity compared to the commercial $\mathrm{CaO}$ in Table 2 . No obvious product layer was observed in the sol-gel $\mathrm{CaO}$ after carbonation at both $400{ }^{\circ} \mathrm{C}$ and $600{ }^{\circ} \mathrm{C}$, as shown in Fig. $6 \mathrm{c}$ and d. The distribution of carbon is consistent between the surface and the inner grains of the sol-gel $\mathrm{CaO}$ grains (Fig. 7e and f). It appears that the carbonation of sol-gel $\mathrm{CaO}$ at $400{ }^{\circ} \mathrm{C}$ is similar to that of commercial $\mathrm{CaO}$, involving the filling of small pores in the $\mathrm{CaO}$ grains with the formed $\mathrm{CaCO}_{3}$. However, the carbonation at $600{ }^{\circ} \mathrm{C}$ is retarded by the lack of useful porosity (the confinement effect) which is required for the growth of $\mathrm{CaCO}_{3}$ instead of the formation of $\mathrm{CaCO}_{3}$ product layer, as shown in Fig. 10b. ${ }^{44}$ This is attributed to that local space is required for the growth of particles from 16.7 to $36.9 \mathrm{~cm}^{3} \mathrm{~mol}^{-1}$ for the conversion of $\mathrm{CaO}$ to $\mathrm{CaCO}_{3}$. The FIB-TEM image of sol-gel FB-600 as shown in Fig. 9C exhibits almost no porosity which is good agreement with the FIB-SEM pictures in Fig. 6d. In addition, the crystal phases $\left(\mathrm{CaCO}_{3}\right.$ and $\left.\mathrm{Ca}(\mathrm{OH})_{2}\right)$ were observed in Fig. 9c, further indicating the formation of $\mathrm{CaCO}_{3}$ in the sol-gel FB-600. Therefore, fabricating nano-CaO having dimensions less than the critical thickness of the $\mathrm{CaCO}_{3}$ layer $(\sim 90 \mathrm{~nm})$ is of potentially great significance if it can be done cheaply and in bulk. For example, nanowire and nanofilm of the novel nano-CaO could be developed. However, the resistance of sorbent sintering during the process of carbonation/calcination remains a challenging topic. Furthermore, it is suggested to disperse $\mathrm{CaO}$ species into an inert support which can provide a certain extent of porosity, prohibit $\mathrm{CaO}$ sintering and play an essential role in restricting the growth of $\mathrm{CaCO}_{3}$ layer.

\section{Conclusions}

The formation of $\mathrm{CaCO}_{3}$ product layer on the outside surface of $\mathrm{CaO}$ grains during the fast reaction stage for carbon capture using two types of $\mathrm{CaO}$ has been systematically studied. It was found that 
for both the commercial $\mathrm{CaO}$ and the sol-gel $\mathrm{CaO}$, two distinct stages of fast carbonation are observed at 400 and $600{ }^{\circ} \mathrm{C}$. After carbonation at $600{ }^{\circ} \mathrm{C}$ for the commercial $\mathrm{CaO}$, a layer of $\mathrm{CaCO}_{3}$ with a thickness around $90 \mathrm{~nm}$ is observed. This is because the internal pores of the commercial $\mathrm{CaO}$ grains have been filled with $\mathrm{CaCO}_{3}$ and a layer of the $\mathrm{CaCO}_{3}$ product is deposited on the outside of the $\mathrm{CaO}$ grain. Here, the fast carbonation stage of the commercial $\mathrm{CaO}$ is terminated by the formation of the $\mathrm{CaCO}_{3}$ layer. However, as with the synthesized sol-gel $\mathrm{CaO}$, the carbonation reaction is retarded by the lack of useful porosity (space is required for the formation of $\mathrm{CaCO} 3$ due to its larger molar volume than $\mathrm{CaO}$ ), defined here as the confinement effect, instead of by the formation of a $\mathrm{CaCO}_{3}$ product layer itself. Thus, a layer of $\mathrm{CaCO}_{3}$ product on the sol-gel $\mathrm{CaO}$ cannot be observed after carbonation at $600{ }^{\circ} \mathrm{C}$. This is attributed to the presence of abundant mesopores generated by the lamellar structure of the sol-gel $\mathrm{CaO}$.

\section{Conflicts of interest}

There are no conflicts to declare.

\section{Acknowledgements}

The authors are grateful for the financial support of the National Natural Science Foundation of China (no. 21706050) and China Scholarship Council (CSC, no. 201606450016).

\section{References}

1. R. Han, J. Gao, S. Wei, Y. Su and Y. Qin, J. Mater. Chem. A, 2018, 6, 3462-3470.

2. Climate change 2014-impacts, adaptation and vulnerability: regional aspects, Intergovernmental Panel on Climate Change, 2014. 
3. W. Obergassel, C. Arens, L. Hermwille, N. Kreibich, F. Mersmann, H. E. Ott and H. WangHelmreich,

4. F. Yan, J. Jiang, M. Zhao, S. Tian, K. Li and T. Li, J. Mater. Chem. A, 2015, 3, 7966-7973.

5. H. Sun, J. Wang, J. Zhao, B. Shen, J. Shi, J. Huang and C. Wu, Appl. Catal. B: Environ., 2019, 244, 63-75.

6. R. S. Haszeldine, Science, 2009, 325, 1647-1652.

7. M. M. Sadiq, H. Li, A. J. Hill, P. Falcaro, M. R. Hill and K. Suzuki, Chem. Mater., 2016, 28, 6219-6226.

8. Z. Sun, M. H. Sedghkerdar, J. Saayman, N. Mahinpey, N. Ellis, D. Zhao and S. Kaliaguine, J. Mater. Chem. A, 2014, 2, 16577-16588.

9. F. Wang and J. Chiou, Energ. Convers. Manage., 2004, 45, 15-26.

10. P. Zhao, J. Sun, Y. Li, K. Wang, Z. Yin, Z. Zhou and Z. Su, Energy Fuels, 2016, 30, 7543-7550.

11. D. P. Hanak, E. J. Anthony and V. Manovic, Energ. Environ. Sci., 2015, 8, 2199-2249.

12. G. Melaet, W. T. Ralston, C. S. Li, S. Alayoglu, K. An, N. Musselwhite, B. Kalkan and G. A. Somorjai, J. Am. Chem. Soc., 2014, 136, 2260-2263.

13. Y. A. Daza, R. A. Kent, M. M. Yung and J. N. Kuhn, Ind. Eng. Chem. Res., 2014, 53, 5828-5837.

14. H. Sun, C. M. Parlett, M. A. Isaacs, X. Liu, G. Adwek, J. Wang, B. Shen, J. Huang and C. Wu, Fuel, 2019, 235, 1070-1076.

15. J. Hilz, M. Helbig, M. Haaf, A. Daikeler, J. Ströhle and B. Epple, Fuel, 2017, 210, 892-899.

16. B. Arias, M. Diego, J. Abanades, M. Lorenzo, L. Diaz, D. Martínez, J. Alvarez and A. Sánchez-Biezma, Int. J. Greenh. Gas Con., 2013, 18, 237-245.

17. M. Chang, W. Chen, C. Huang, W. Liu, Y. Chou, W. Chang, W. Chen, J. Cheng, K. Huang and H. Hsu, Energy Procedia, 2014, 63, 2100-2108.

18. P. Sun, J. Grace, C. Lim and E. Anthony, AIChE J., 2007, 53, 2432-2442. 
20. A. I. Lysikov, A. N. S. And and A. G. Okunev, Ind. Eng. Chem. Res., 2007, 46, 4633-4638.

21. S. Choi, J. H. Drese and C. W. Jones, ChemSusChem, 2009, 2, 796-854.

22. R. Barker, J. Appl. Chem. Biotech., 1973, 23, 733-742.

23. H. Sun, C. Wu, B. Shen, X. Zhang, Y. Zhang and J. Huang, Mater. Today Sustain., 2018, 1, 1-27.

24. A. Kierzkowska, R. Pacciani and C. Müller, ChemSusChem, 2013, 6, 1130-1148.

25. F. Campbell, A. Hills and A. Paulin, Chem. Eng. Sci., 1970, 25, 929-942.

26. B. Arias, J. Abanades and G. S. Grasa, Chem. Eng. J., 2011, 167, 255-261.

27. J. M. Valverde, J. Mater. Chem. A, 2013, 1, 447-468.

28. F. Liu, W. Li, B. Liu and R. Li, J. Mater. Chem. A, 2013, 1, 8037-8044.

29. D. Mess, A. F. Sarofim and J. P. Longwell, Energy Fuels, 1999, 13, 999-1005.

30. D. Alvarez and J. C. Abanades, Ind. Eng. Chem. Res., 2005, 44, 5608-5615.

31. V. Nikulshina, M. E. Galvez and A. Steinfeld, Chem. Eng. J., 2007, 129, 75-83.

32. G. MontesHernandez, R. Chiriac, F. Toche and F. Renard, Int. J. Greenh. Gas Con., 2012, 11, $172-180$.

33. H. Gupta and L. Fan, Ind. Eng. Chem. Res., 2002, 41, 4035-4042.

34. M. S. Duyar, M. A. A. Trevino and R. J. Farrauto, Appl. Catal. B: Environ., 2015, 168, 370-376.

35. E. Santos, C. Alfonsín, A. Chambel, A. Fernandes, A. S. Dias, C. Pinheiro and M. Ribeiro, Fuel, 2012, 94, 624-628.

36. Y. Hu, W. Liu, J. Sun, X. Yang, Z. Zhou, Y. Zhang and M. Xu, Energy Fuels, 2016, 30, 6606-6613.

37. B. C. Lippens and J. De Boer, J. Catal., 1965, 4, 319-323.

38. C. Luo, Y. Zheng, C. Zheng, J. Yin, C. Qin and B. Feng, Int. J. Greenh. Gas Con., 2013, 12, 193-199.

39. M. Broda, A. M. Kierzkowska and C. R. Müller, ChemSusChem, 2012, 5, 411-418.

40. S. Bhatia and D. Perlmutter, AIChE J, 1983, 29, 79-86.

41. H. Zhu, Z. Liu, Y. Wang, D. Kong, X. Yuan and Z. Xie, Chem. Mater., 2007, 20, 1134-1139.

42. C. Wu and P. T. Williams, Appl. Catal. B: Environ., 2010, 96, 198-207. 
393 44. J. C. Abanades and D. Alvarez, Energy Fuels, 2003, 17, 308-315.

394 45. A. Lucas, M. Mouallem-Bahout, C. Carel, J. Gaudé and M. Matecki, J. Solid State Chem., 1999, 146, $73-78$.

395 46. W. Liu, J. S. Dennis, D. S. Sultan, S. A. Redfern and S. A. Scott, Chem. Eng. Sci., 2012, 69, $644-658$.

47. A. Biasin, C. U. Segre, G. Salviulo, F. Zorzi and M. Strumendo, Chem. Eng. Sci., 2015, 127, 13-24.

397

48. Y. Kong, G. Jiang, M. Fan, X. Shen, S. Cui and A. G. Russell, Chem. Commun., 2014, 50, 12158-12161.

398

399 
400

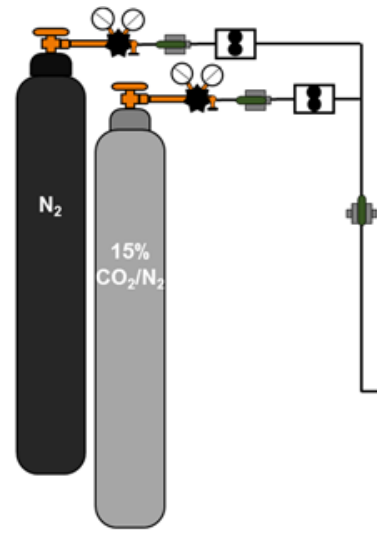

401

402

403

a

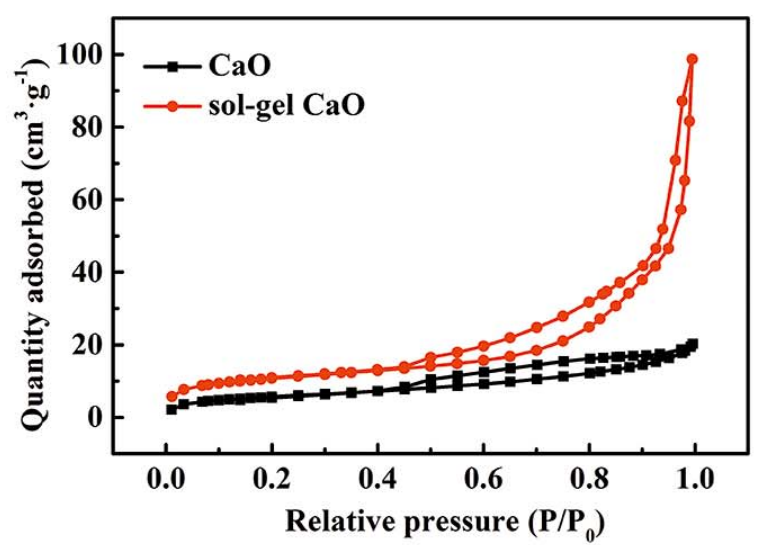

b

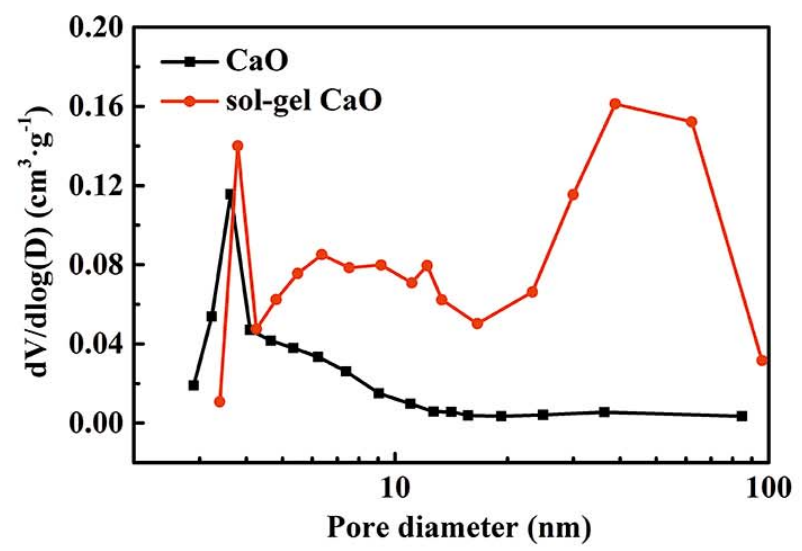

404

405

406

407

Fig. 1 Schematic diagram of the atmospheric carbonation/calcination reactor system (fixed bed). 

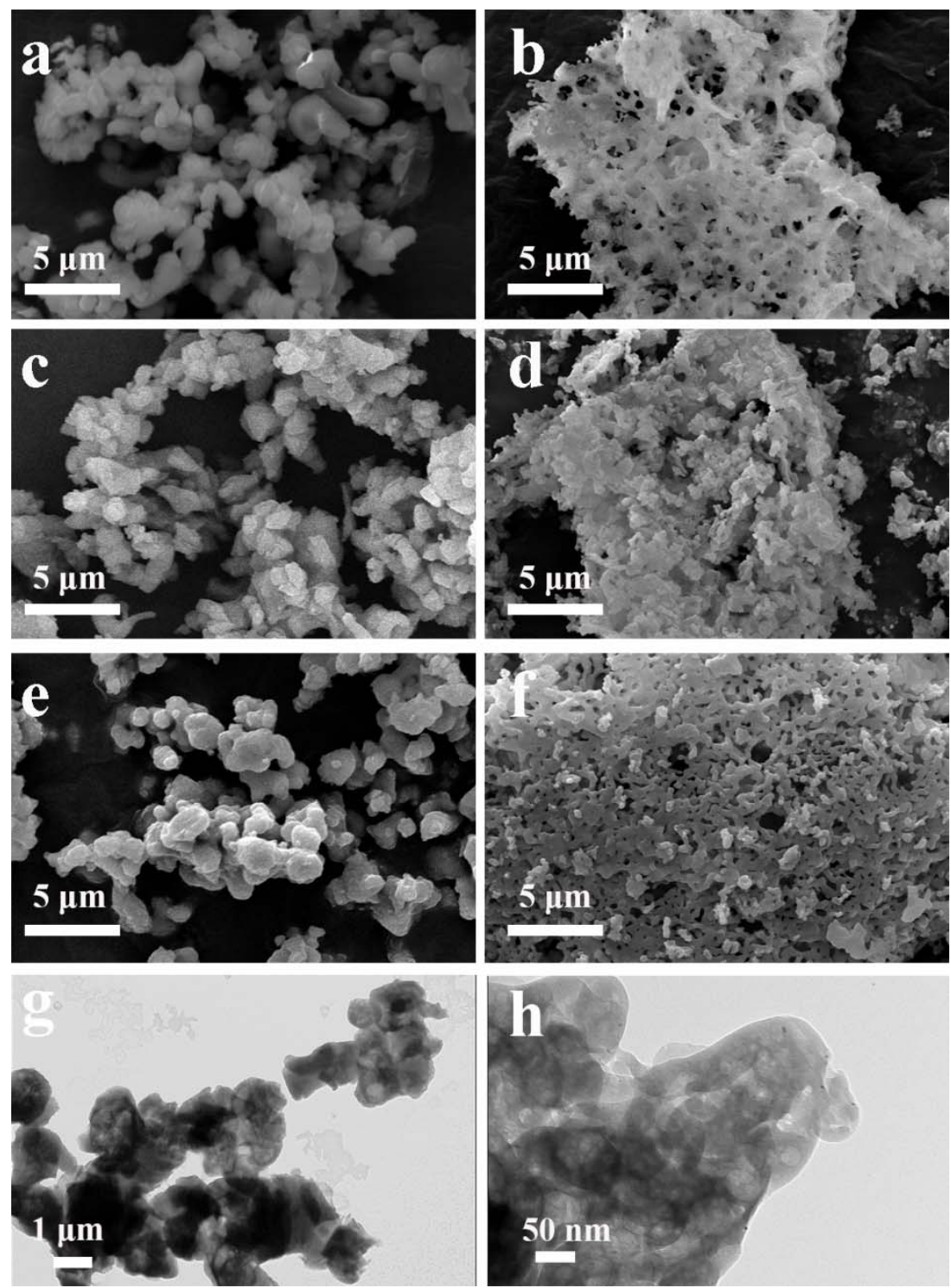

409 Fig. 3 SEM images of a) $\mathrm{CaO}$, b) sol-gel $\mathrm{CaO}$, c) FB-400, d) sol-gel FB-400, e) FB-600, f) sol-gel

FB-600 and TEM images of g) $\mathrm{CaO}$, h) sol-gel $\mathrm{CaO}$. 

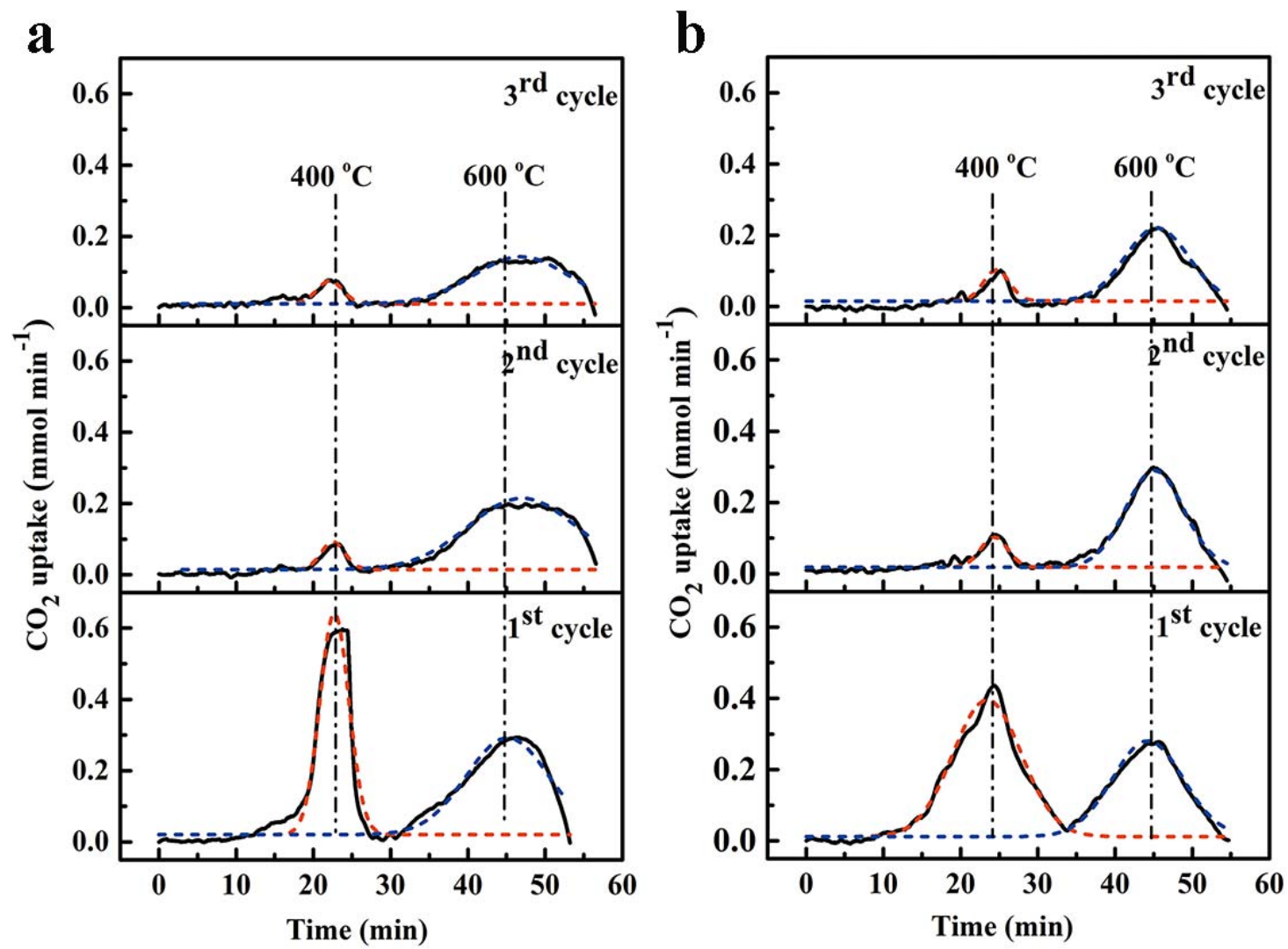

Fig. 4 Cyclic $\mathrm{CO}_{2}$ capture performance of a) $\mathrm{CaO}$, b) sol-gel $\mathrm{CaO}$, in a fixed-bed reactor (black line: experimental curves; red dashed curve: peak I, carbonation at $400{ }^{\circ} \mathrm{C}$, blue dashed curve: peak II, carbonation at $\left.600{ }^{\circ} \mathrm{C}\right)$.
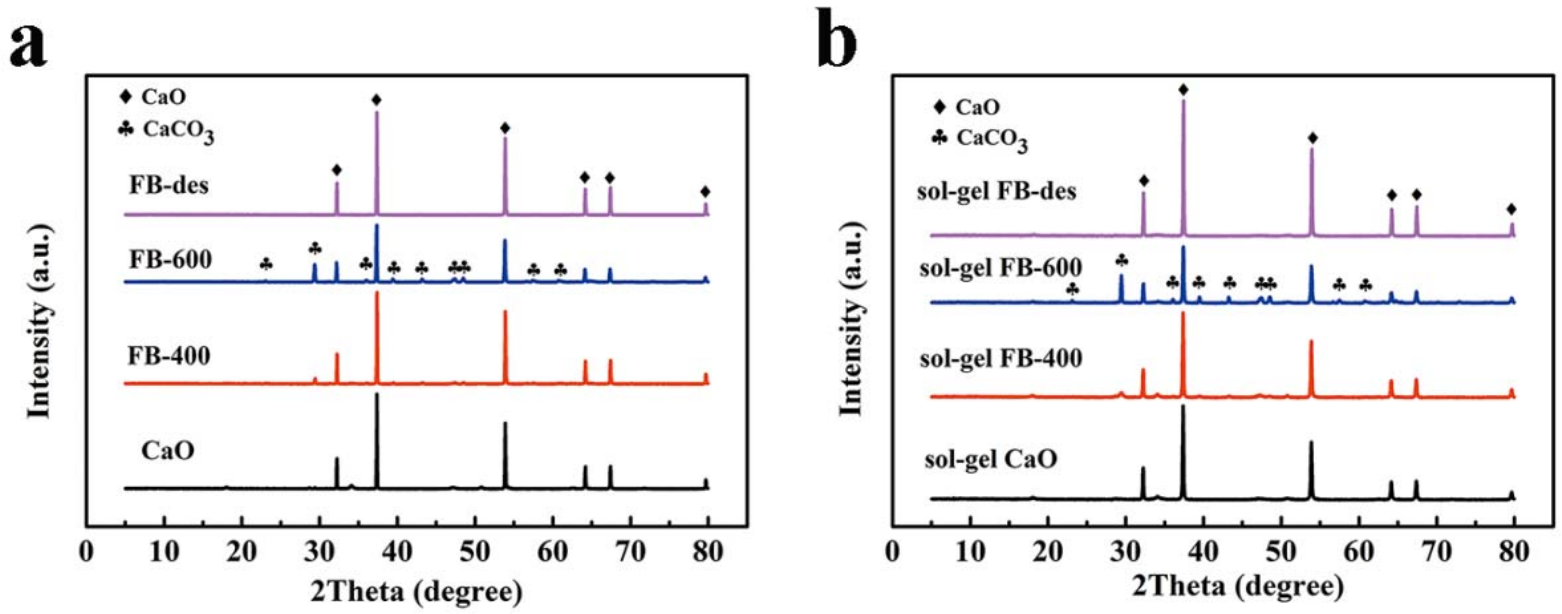

Fig. 5 XRD patterns for $\mathrm{CaO}$ adsorbents obtained after reaching highest reaction rate at different 

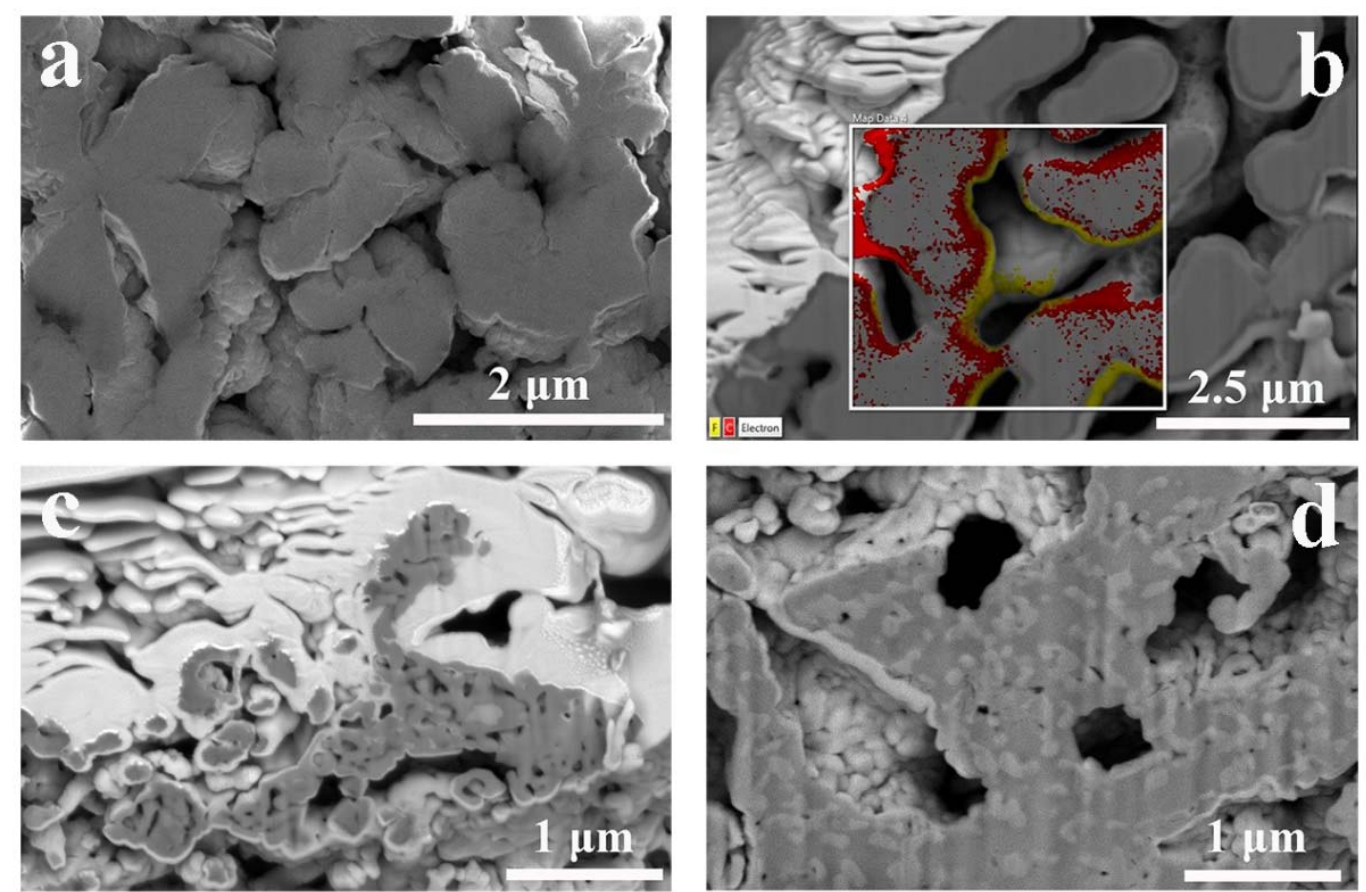

Ca Wt\%

$\mathrm{OWt} \%$

$\mathrm{CWt} \%$
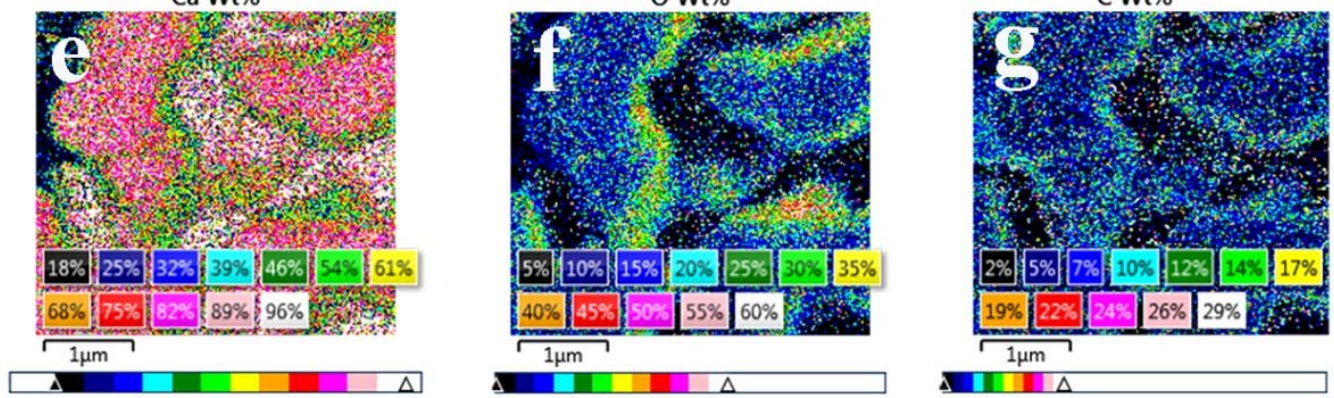

419 Fig. 6 FIB-SEM images coupled with EDX mapping of the cross-section product layer. a) FB-400,

420 b) FB-600, c) sol-gel FB-400, d) sol-gel FB-600, e) Ca element mapping, f) O element mapping, g) 

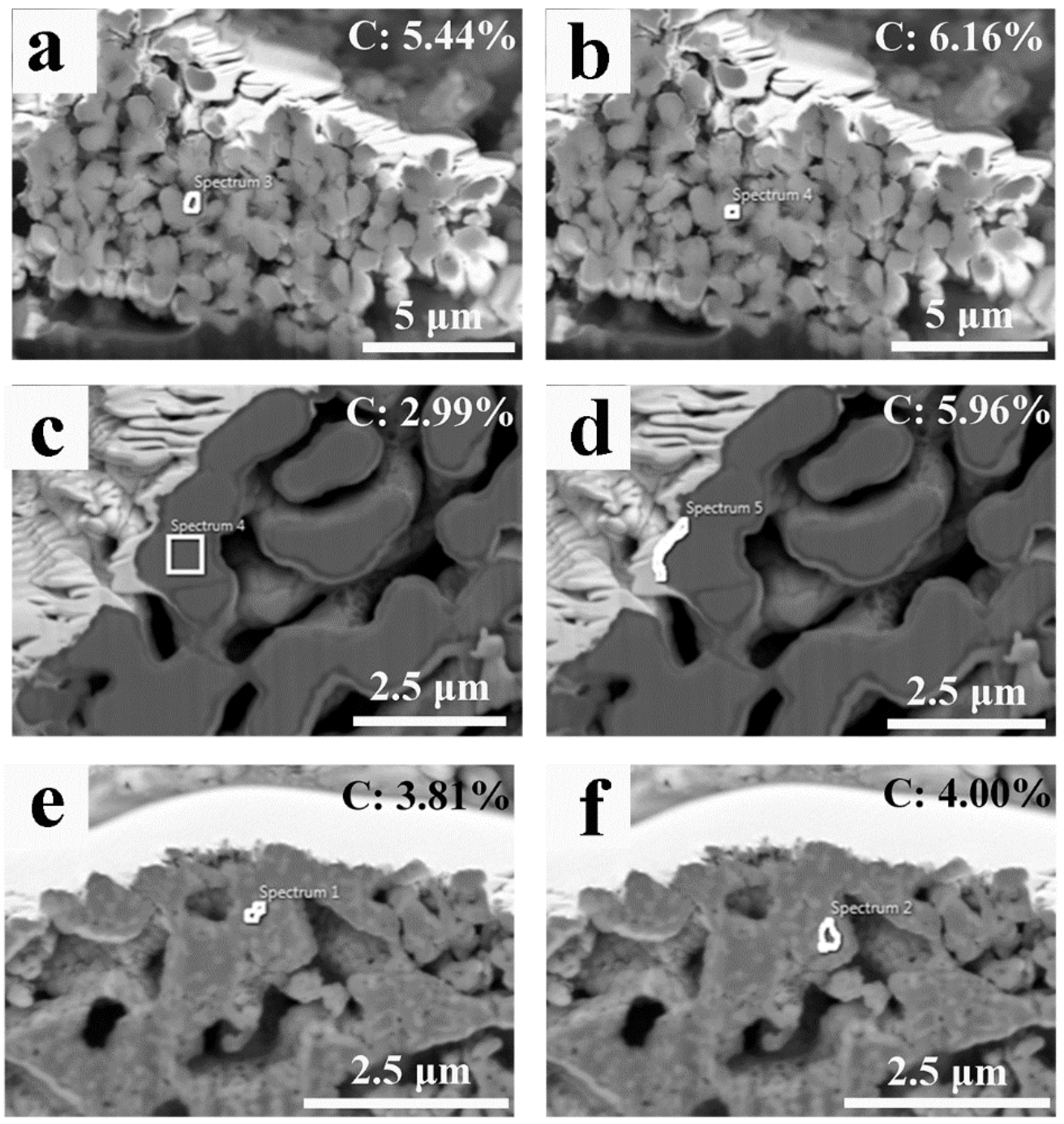

424 Fig. 7 FIB-SEM images and carbon element percentage of a and b) FB-400, c and d) FB-600, and e and f) sol-gel FB-600. 

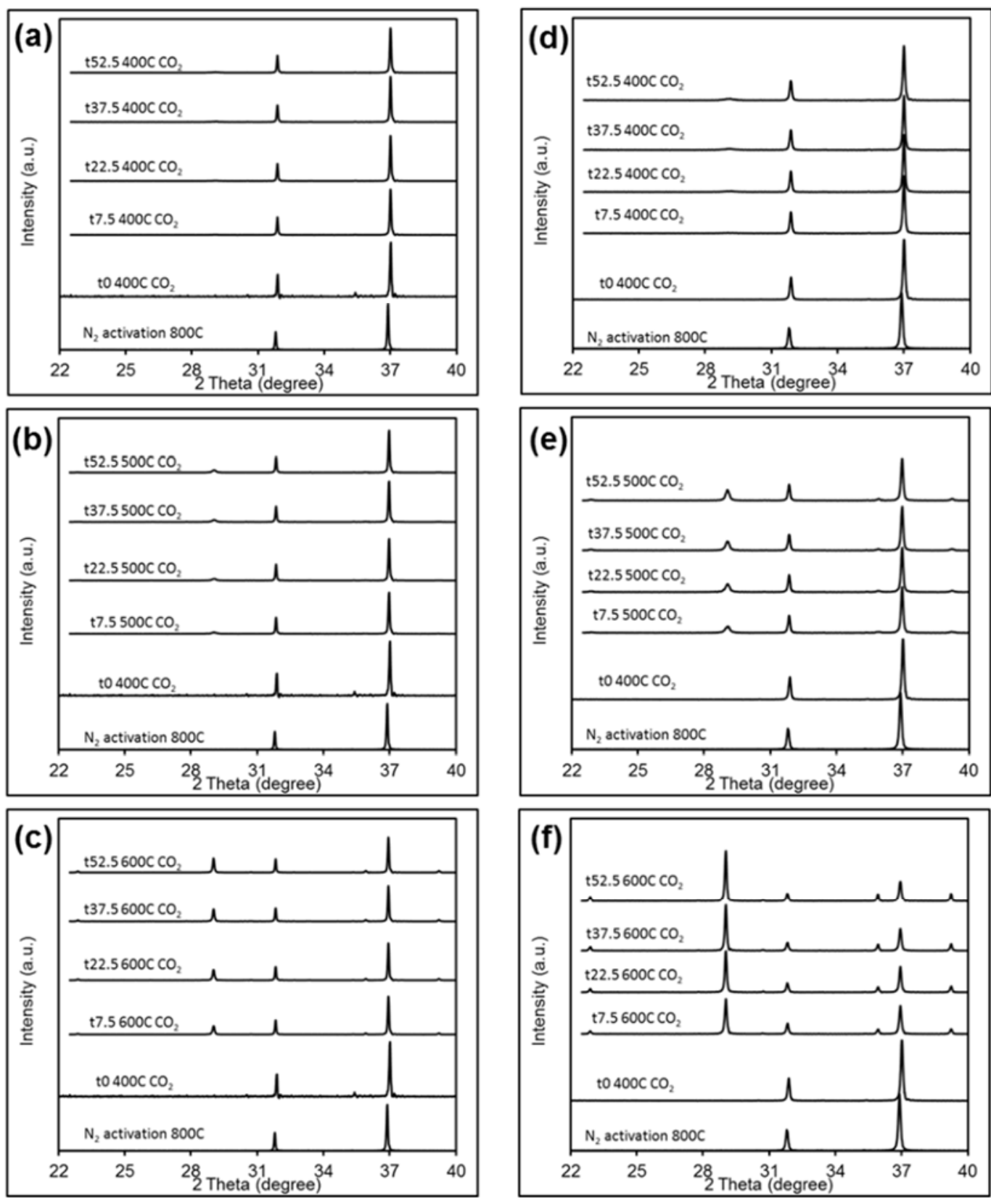

427 Fig. $8 \mathrm{In}$-situ XRD patterns of $\mathrm{CaO}$ adsorbents at different temperatures. a) $\mathrm{CaO} 400{ }^{\circ} \mathrm{C}$, b) $\mathrm{CaO}$ $428500{ }^{\circ} \mathrm{C}$, c) $\mathrm{CaO} 600{ }^{\circ} \mathrm{C}$, d) sol-gel $\mathrm{CaO} 400{ }^{\circ} \mathrm{C}$, e) sol-gel $\mathrm{CaO} 500{ }^{\circ} \mathrm{C}$, f) sol-gel $\mathrm{CaO} 600{ }^{\circ} \mathrm{C}($ txy.z represents carbonation for xy.z min). 

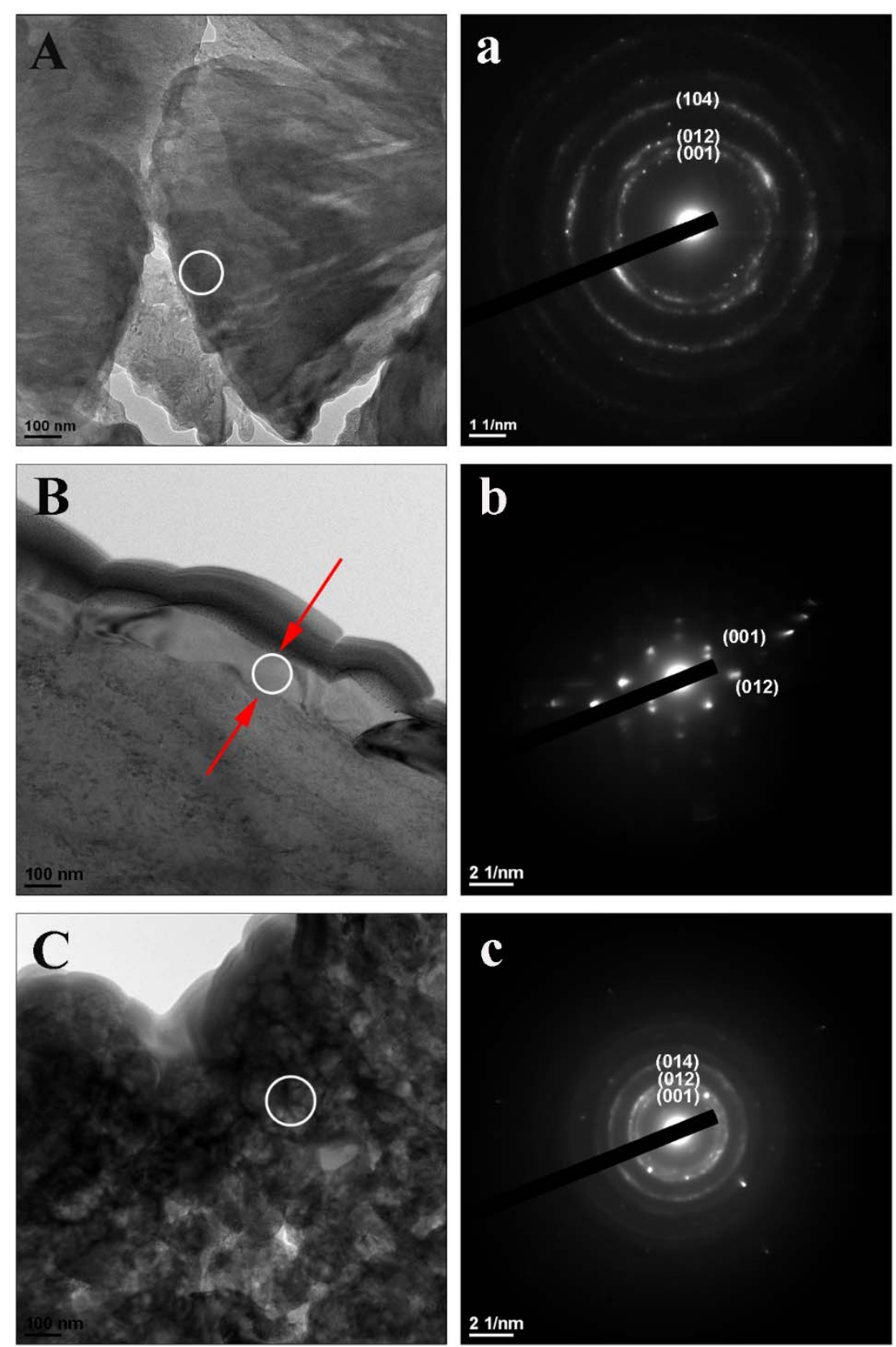

431 Fig. 9 FIB-TEM images and selected-area electron diffraction pattern of the cross-section product 
$\mathbf{a}$
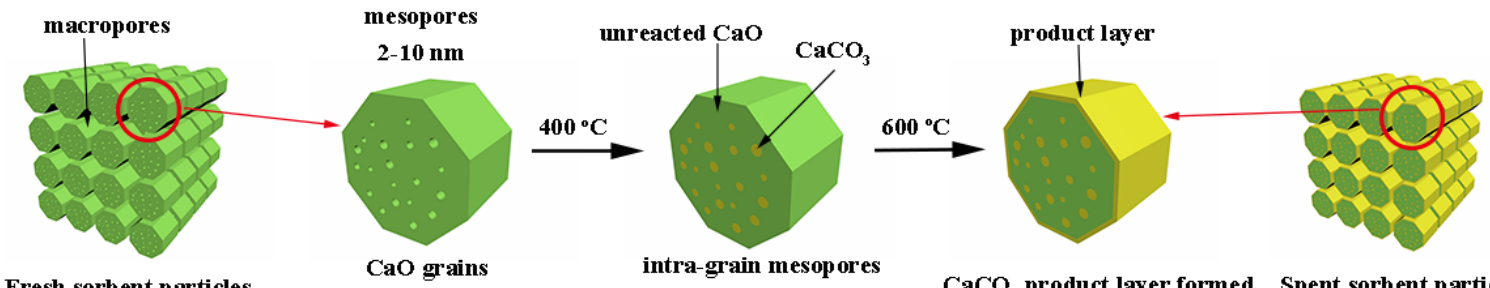

Fresh sorbent particles

$\sim 1.5 \mu \mathrm{m}$ filled up with $\mathrm{CaCO}_{3}$

$\mathrm{CaCO}_{3}$ product layer formed Spent sorbent particles

b

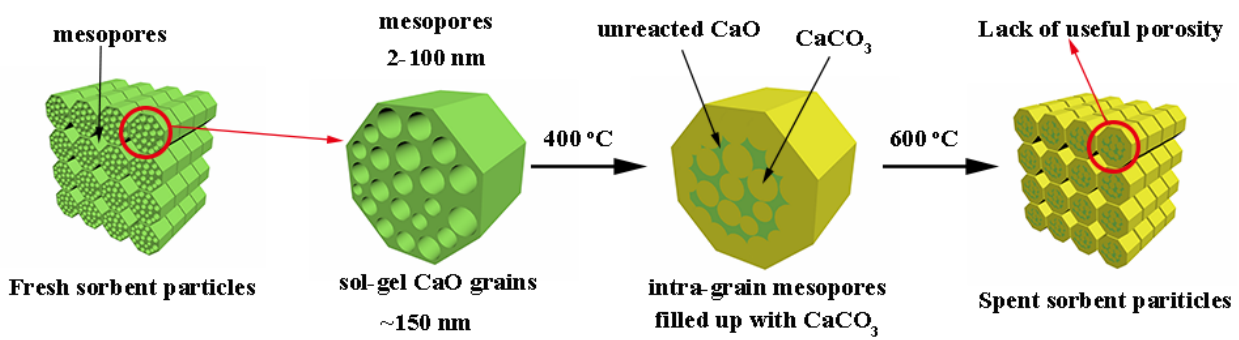

Fig. 10 Schematic illustration of the effect of temperature and structure on the $\mathrm{CaCO}_{3}$ layer 
Table 1 Textural properties derived from different $\mathrm{CaO}$ adsorbents

\begin{tabular}{|c|c|c|c|c|c|c|}
\hline Samples & $\begin{array}{c}S_{\mathrm{BET}^{\mathrm{a}}} \\
\left(\mathrm{m}^{2} \mathrm{~g}^{-1}\right)\end{array}$ & $\begin{array}{l}S_{\text {micro }} \mathrm{b} \\
\left(\mathrm{m}^{2} \mathrm{~g}^{-1}\right)\end{array}$ & $\begin{array}{c}S_{\mathrm{meso}} \mathrm{c} \\
\left(\mathrm{m}^{2} \mathrm{~g}^{-1}\right)\end{array}$ & $\begin{array}{c}V_{p^{d}} \\
\left(\mathrm{~cm}^{3} \mathrm{~g}^{-1}\right)\end{array}$ & $\begin{array}{c}V_{\text {micro }}{ }^{\mathrm{e}} \\
\left(\mathrm{cm}^{3} \mathrm{~g}^{-1}\right)\end{array}$ & $\begin{array}{c}V_{\text {meso }}{ }^{\mathrm{f}} \\
\left(\mathrm{cm}^{3} \mathrm{~g}^{-1}\right)\end{array}$ \\
\hline $\mathrm{CaO}$ & 20.96 & 3.70 & 17.26 & 0.0314 & 0.0014 & 0.0331 \\
\hline sol-gel $\mathrm{CaO}$ & 38.51 & 8.51 & 30.00 & 0.1527 & 0.0035 & 0.1511 \\
\hline \multicolumn{7}{|c|}{${ }^{\mathrm{a} B E T}$ surface areas } \\
\hline \multicolumn{7}{|c|}{${ }^{b}$ Micropore surface areas calculated by t-plot method } \\
\hline \multicolumn{7}{|c|}{${ }^{\mathrm{c}}$ Mesopore surface areas equal to $\mathrm{S}_{\mathrm{BET}}$ minus $\mathrm{S}_{\text {micro }}$} \\
\hline \multicolumn{7}{|c|}{${ }^{\mathrm{d}}$ Total pore volume measured at a relative pressure $\left(\mathrm{P} / \mathrm{P}_{0}\right)$ of 0.99} \\
\hline \multicolumn{7}{|c|}{${ }^{\mathrm{e}}$ The t-plot micropore volume } \\
\hline
\end{tabular}

445

Table $2 \mathrm{CO}_{2}$ uptake of a commercial $\mathrm{CaO}$ and a sol-gel $\mathrm{CaO}$ at different temperatures in a 447 fixed-bed reactor

\begin{tabular}{ccccccc}
\hline \multirow{2}{*}{$\mathrm{CO}_{2}$ uptake } & \multicolumn{2}{c}{$1^{\text {st }}$ cycle } & \multicolumn{2}{c}{$2^{\text {nd }}$ cycle } & \multicolumn{2}{c}{$3^{\text {rd }}$ cycle } \\
\cline { 2 - 7 }$\left(\mathrm{mmol} \mathrm{g}^{-1}\right)$ & $400{ }^{\circ} \mathrm{C}$ & $600{ }^{\circ} \mathrm{C}$ & $400{ }^{\circ} \mathrm{C}$ & $600{ }^{\circ} \mathrm{C}$ & $400{ }^{\circ} \mathrm{C}$ & $600{ }^{\circ} \mathrm{C}$ \\
\hline $\mathrm{CaO}$ & 5.84 & 7.26 & 0.60 & 7.02 & 0.54 & 4.06 \\
sol-gel CaO & 8.50 & 6.16 & 0.76 & 5.12 & 0.74 & 4.20 \\
\hline
\end{tabular}

